\title{
Experimental Investigations of Phase Equilibria in Ternary Ag-Cu-Ga System
}

\author{
D. Jendrzejczyk-Handzlik ${ }^{1}$ P. Handzlik ${ }^{1}$ - K. Fitzner ${ }^{1}$
}

Submitted: 30 July 2018/in revised form: 11 November 2018/Published online: 27 November 2018

(C) The Author(s) 2018

\begin{abstract}
Experimental study of phase equilibria in the ternary Ag-Cu-Ga system was carried out by using DTA/ DSC, isothermal equilibration and microscopic as well as $\mathrm{x}$-ray analyses. DTA experiments were conducted for alloys, whose concentrations varied along two cross-sections determined by the ratio of mole fractions $x_{\mathrm{Ag}} / x_{\mathrm{Cu}}$ $=1: 1$ and $x_{\mathrm{Ag}} / x_{\mathrm{Ga}}=1: 1$. Equilibration of samples was carried out at 200,450 and $650{ }^{\circ} \mathrm{C}$. The obtained information about phases in equilibrium was compared with the results of calculations of the phase diagram for conditions identical to our experiments. It was demonstrated that the results of calculations are compatible with the experimental data.
\end{abstract}

Keywords Ag-Cu-Ga system - CALPHAD method - DTA measurements $\cdot$ phase equilibria $\cdot$ scanning electron microscopy $\cdot \mathrm{x}$-ray diffraction

This invited article is part of a special issue of the Journal of Phase Equilibria and Diffusion in honor of Prof. Jan Vrestal's 80th birthday. This special issue was organized by Prof. Andrew Watson, Coventry University, and Dr. Ales Kroupa, Institute of Physics of Materials, Brno, Czech Republic.

\footnotetext{
D. Jendrzejczyk-Handzlik djendrze@agh.edu.pl

K. Fitzner

fitzner@agh.edu.pl

1 Faculty of Non-Ferrous Metals, AGH University of Science and Technology, 30 Mickiewicza Ave., 30-059 Kraków, Poland
}

\section{Introduction}

Growing interest in gallium applications in alloys stimulated research on thermodynamic properties and phase equilibria in gallium multicomponent systems. Gallium exhibits low melting point $(303 \mathrm{~K})$ and high boiling point (about $2673 \mathrm{~K}$ ), thus it is not surprising that in thermometers it can substitute mercury, which is toxic. It was found that eutectic alloy of gallium, indium and tin (Galinstan), which melts below the freezing point of water, can be applied not only in thermometers as a liquid up to $1573 \mathrm{~K},{ }^{[1]}$ but also in microchannel heat sinks ${ }^{[2]}$ in cooling systems. Moreover, low melting point of gallium and its alloys can be exploited in the process of not only microelectronics bonding, but also in low temperature joint fabrication between refractory metals during isothermal solidification while using the amalgam as a solvent. ${ }^{[3,4]}$ Also, small additions of gallium to the $\mathrm{Ag}-\mathrm{Cu}-\mathrm{Sn}$ lead-free solder were introduced to lower the melting points and to change wettability of this solder. ${ }^{[5]}$

As far as solid gallium alloys are concerned, it was found that gallium addition to gold results in bright-blue color, which is exploited in jewelry. ${ }^{[6-8]}$ Addition of gallium into gold-palladium and copper-palladium alloys led to the production of a new type of fillings in dentistry. ${ }^{[9,10]}$ Shape memory Ni-Mn-Ga alloys containing about $20 \%$ of gallium are known to exhibit a giant magneto-mechanical effect, which makes it possible to change the mechanical properties of the material by interaction with the magnetic field. $^{[11,12]}$

For years, gallium has been found in alloys used in electronic devices. Apart from a well-known example of gallium arsenide, which is excellent III-V semiconductor used in optoelectronics and recently in photonic quantum technologies, ${ }^{[13]}$ gallium is also present in chips applied in 
printed circuit boards ${ }^{[14]}$ and LEDs used for background lighting. ${ }^{[15]}$

Needless to say, the 2014 Nobel Prize in Physics was awarded for work on blue-light-emitting diodes (LEDs) based on gallium nitride. ${ }^{[16]}$ Recently, a new type of materials based on $\mathrm{Cu}-\mathrm{In}$-Ga-Se alloys (so-called CIGS) was developed, which is used in solar cells. ${ }^{[17,18]}$ It is claimed that after Ag addition these thin film solar cells (ACIGS) reached the efficiency of almost $20 \% .{ }^{[19]}$ Thus, there is a mounting evidence that gallium alloys can be interesting future materials.

However, despite these various applications, multicomponent phase diagrams of gallium alloys are rarely known. For example, very little is known about the phase relationships and their stability in the Au-Cu-Ga and $\mathrm{Ag}$ $\mathrm{Cu}-\mathrm{Ga}$ ternary systems. In fact, the $\mathrm{Ag}-\mathrm{Cu}-\mathrm{Ga}$ phase diagram is not known. In the literature only one paper by Markiv et al. ${ }^{[20]}$ can be found, in which the isothermal section at $450{ }^{\circ} \mathrm{C}$ is shown. Recently, we conducted a series of investigations enabling us to provide the description of thermodynamic properties of the liquid phases as well as re-optimization of Ag- $\mathrm{Ga}^{[21,22]}$ and $\mathrm{Cu}-$ $\mathrm{Ga}^{[23,24]}$ binary systems. Finally, attempts have been made to complete thermodynamic modeling of the $\mathrm{Ag}-\mathrm{Cu}-\mathrm{Ga}$ system. ${ }^{[25]}$ In this paper, the experimental results concerning the investigation of phase equilibria in this ternary system are reported.

\section{Experimental}

\subsection{Materials}

Metallic copper, gallium and silver were obtained from Alfa Aesar, Germany. They were with minimum mass fractions purities of $99.9999 \%(\mathrm{Cu}, \mathrm{Ag})$ and $99.99 \%(\mathrm{Ga})$.

\subsection{DTA Measurements}

DTA measurements were carried out on Ag-Cu-Ga alloys along two cross-sections, where $x_{\mathrm{Ag}} / x_{\mathrm{Ga}}=1: 1$ and $x_{\mathrm{Cu}} /$ $x_{\mathrm{Ga}}=1: 1$, and in the temperature range from 50 to $1070{ }^{\circ} \mathrm{C}$. The samples of the alloys were prepared from pieces of pure elements. The weight of samples used for the experiments was about $250 \mathrm{mg}$ prepared for DTA experiments with the following compositions: $x_{\mathrm{Ag}} / x_{\mathrm{Ga}}$ $=1: 1$ for $x \mathrm{Cu}$ from 0.1 to 0.8 and $x_{\mathrm{Cu}} / x_{\mathrm{Ag}}=1: 1$ for $x \mathrm{Ga}$ from 0.3 to 0.8 .

The samples were placed inside the self-made DTA quartz crucibles, and then they were sealed under vacuum. Next, the samples were annealed in the operating furnace VMK22, Linn High Therm for 8 weeks at the temperature of $200{ }^{\circ} \mathrm{C}$ to obtain thermodynamic equilibrium and quenched in ice water. After annealing they were transferred to the DTA apparatus. The measurements were performed on DTA 404 apparatus from Netzsch, Selb, Germany. This device is hooked up to a PC in order to control all DTA procedures during the experiment by PROTEUS software, also obtained from Netzsch. The acquired data were recorded on the PC. The total experimental error of the method has been estimated to be \pm $2{ }^{\circ} \mathrm{C}$. The experiments were carried out at the rate of $10 \%$ min in two heating and cooling cycles. The working side was a ternary alloy of the chosen composition sealed in self-made DTA quartz crucibles while the empty self-made DTA quartz crucible was the reference side. Next, the obtained results were used to estimate the temperature of phase transformations and liquidus, starting from the annealing temperature up to about $200{ }^{\circ} \mathrm{C}$.

\subsection{SEM and XRD Analysis}

To analyze the phase equilibria existing in the $\mathrm{Ag}-\mathrm{Cu}-\mathrm{Ga}$ ternary system, 30 alloys with different compositions were prepared. Table 4 lists the nominal alloy compositions investigated in the Ag-Cu-Ga ternary system together with annealing temperatures. All ternary alloys were prepared from pure elements: $\mathrm{Ag}, \mathrm{Cu}$ and $\mathrm{Ga} .30$ samples (total mass about $0.50 \mathrm{~g}$ ) were sealed and melted in evacuated quartz tubes. After alloying, the samples were homogenized in two separately operating furnaces at first at $1200{ }^{\circ} \mathrm{C}$ for $10 \mathrm{~h}$. Then, they were annealed in another furnace (Linn High Therm VMK 10) at $200{ }^{\circ} \mathrm{C}$ (samples 1-15), $450{ }^{\circ} \mathrm{C}$ (samples 16-24) and $650^{\circ} \mathrm{C}$ (samples 24-30) for 8 weeks to form equilibrium phases. After this equilibrium treatment, the tubes were quenched in cold water. The quenched ternary alloys were put into conductive resin and polished with diamond abrasive spray down to $1 \mu \mathrm{m}$ grain size. Microstructures of the alloys were systematically investigated by light optical microscopy (Nikon Eclipse LV150). Next, a thorough investigation of each sample was done by using a scanning electron microscopy (Hitachi SU70) in back-scattered mode (BSE) in order to reveal the compositional contrast between the different phases. All samples were studied by point and region analyses using EDS analysis (Thermo Scientific) attached to the SEM to obtain chemical composition of the phases. Point analyses were performed over five points or areas in each phase. Data acquisition and calculations of chemical composition were done by using NSS 3 software. Generally, for each element an error within 0.2 at.\% was ascribed. After investigation of microstructure, each sample was subjected to $\mathrm{x}$-ray diffraction (XRD, Rigaku, Mini Flex II) using monochromatic $\mathrm{Cu} \mathrm{K} \alpha$ radiation $(0.15416 \mathrm{~nm})$. XRD spectra were solved by using PDXL software (Rigaku) with ICDD PDF 2 + Release 2010 database. 
Table 1 Information on phases in the constituent binary systems according to the literature

\begin{tabular}{|c|c|c|c|c|}
\hline Phase & Thermodynamic database name & Strukturbericht designation & Pearson symbol & Space group \\
\hline$(\mathrm{Ag})$ & FCC_A1 & A1 & $\mathrm{cF} 4$ & $F m \overline{3} m$ \\
\hline$(\mathrm{Cu})$ & FCC_A1 & A1 & $\mathrm{cF} 4$ & $F m \overline{3} m$ \\
\hline$\zeta-\mathrm{Ag}_{2} \mathrm{Ga}$ & HCP_A3 & A3 & $\mathrm{hP} 2$ & $P 6_{3} / m m c$ \\
\hline$\zeta^{\prime}-\mathrm{Ag}_{2} \mathrm{Ga}$ & HCP_ORD & $\mathrm{C} 22$ & hP9 & $P \overline{6} 2 m$ \\
\hline $\mathrm{Ag}_{3} \mathrm{Ga}_{2}$ & AG3GA2 & $\cdots$ & $\cdots$ & Pmmm \\
\hline$\beta$ & BCC_A2 & A2 & $\mathrm{cI} 2$ & $\operatorname{Im} \overline{3} m$ \\
\hline$\zeta$ & HCP_A3 & A3 & $\mathrm{hP} 2$ & $P 6_{3} / m m c$ \\
\hline$\zeta^{\prime}$ & CU0.778GA0.222 & $\cdots$ & $\ldots$ & $\ldots$ \\
\hline$\gamma_{0}$ & GAMMA_DIS & $\mathrm{D}_{3}$ & cP52 & $P \overline{4} 3 m$ \\
\hline$\gamma_{1}$ & GAMMA_ORD & $\mathrm{D}_{3}$ & $\mathrm{cP52}$ & $P \overline{4} 3 m$ \\
\hline$\gamma_{2}$ & GAMMA_2 & $\ldots$ & $\mathrm{cP} ?$ & $P \overline{4} 3 m$ \\
\hline$\gamma_{3}$ & GAMMA_3 & $\cdots$ & $\mathrm{cP} ?$ & $P \overline{4} 3 m$ \\
\hline $\mathrm{CuGa}_{2}$ & CUGA2 & $\ldots$ & $\mathrm{tP} 3$ & $\mathrm{P} 4 / \mathrm{mmm}$ \\
\hline$(\mathrm{Ga})$ & ORTHO_GA & A11 & oC8 & Cmca \\
\hline
\end{tabular}

\section{Thermodynamic Calculation}

Table 1 summarizes stable phases in the ternary Ag-Cu-Ga system and their crystallographic data based on the literature. The binary $\mathrm{Ag}-\mathrm{Cu}$ system includes 3 phases: liquid and two solid solutions ( $\mathrm{Ag})$ and $(\mathrm{Cu})$. The binary Ag-Ga system includes 6 phases: solid solution of gallium in silver (Ag), Orthorhombic_GA (Ga), $\quad \zeta \quad$ (HCP_A3), $\zeta^{\prime}$ (HCP_ORD), $\mathrm{Ag}_{3} \mathrm{Ga}_{2}$ and the liquid phase. Finally, the $\mathrm{Cu}-$ Ga system includes the following phases: solid solution of gallium in copper $(\mathrm{Cu}), \beta$ (BCC_A2), $\zeta$ (HCP_A3), $\zeta^{\prime}$ (CU0.778GA0.222), $\gamma_{0}, \gamma_{1}, \gamma_{2}, \gamma_{3}, \mathrm{CuGa}_{2}$ and the liquid phase.

Optimized binary thermodynamic parameters for the $\mathrm{Ag}-\mathrm{Cu}$ binary system used in this study were taken from COST 531 database, ${ }^{[26]}$ for the Ag-Ga system from Gierlotka and Jendrzejczyk-Handzlik ${ }^{[22]}$ and for the $\mathrm{Cu}-\mathrm{Ga}$ system from the work of Jendrzejczyk-Handzlik et al. ${ }^{[24]} \mathrm{In}$ turn, ternary parameters were derived during optimization of Ag-Cu-Ga system. ${ }^{[25]}$ The binary and ternary thermodynamic parameters used for the calculation of phase equilibria in the ternary $\mathrm{Ag}-\mathrm{Cu}-\mathrm{Ga}$ system are listed in Table 2.

The experimental results were superimposed on isopleths calculated along two cross-sections, and on isothermal sections calculated at three chosen temperatures. Thermodynamic calculations were performed by using Pandat 2018 software. $^{[28]}$

\section{Results and Discussion}

\subsection{DTA Measurements}

As a result of DTA measurements, phase transition temperatures and the liquidus line along two selected crosssections, namely $x_{\mathrm{Ag}} / x_{\mathrm{Cu}}=1: 1$ and $x_{\mathrm{Ag}} / x_{\mathrm{Ga}}=1: 1$, in the $\mathrm{Ag}-\mathrm{Cu}-\mathrm{Ga}$ system were determined. Temperatures of liquidus line and other phase transformations were taken from DTA curves for first heating and cooling cycles for every studied sample (the liquidus temperatures were taken from the peak maximum temperature on heating and on cooling from the corresponding onset). The obtained results from DTA experiments are gathered in Table 3.

In Table 3 sample compositions, temperatures of four invariant reactions and liquidus temperatures which were determined by using DTA measurements are given.

Examples of curves recorded for a chosen composition of ternary $\mathrm{Ag}_{30} \mathrm{Cu}_{40} \mathrm{Ga}_{30}$ alloy, which were determined experimentally using DTA method, are shown in Fig. 1. All experiments were run with the rate $10 \% \mathrm{~min}$ and they showed clearly detected phase transitions.

The determined temperature of invariant reaction $\mathrm{L}+\gamma_{3} \rightarrow \mathrm{Ag}_{3} \mathrm{Ga}_{2}+\mathrm{CuGa}_{2}$ is based on seven samples (five samples from the cross-section where $x_{\mathrm{Ag}} / x_{\mathrm{Cu}}=1: 1$ and two samples from the cross-section where $x_{\mathrm{Ag}} / x_{\mathrm{Ga}-}$ $=1: 1)$. This reaction temperature was found to be in the temperature interval from 245 to $255^{\circ} \mathrm{C}$. The calculated temperature of this invariant reaction is $240{ }^{\circ} \mathrm{C}$. The analysis of the experimentally determined values given in Table 3 has shown that in case of the two samples taken from cross section $x_{\mathrm{Ag}} / x_{\mathrm{Cu}}=1: 1$, and of the composition of 


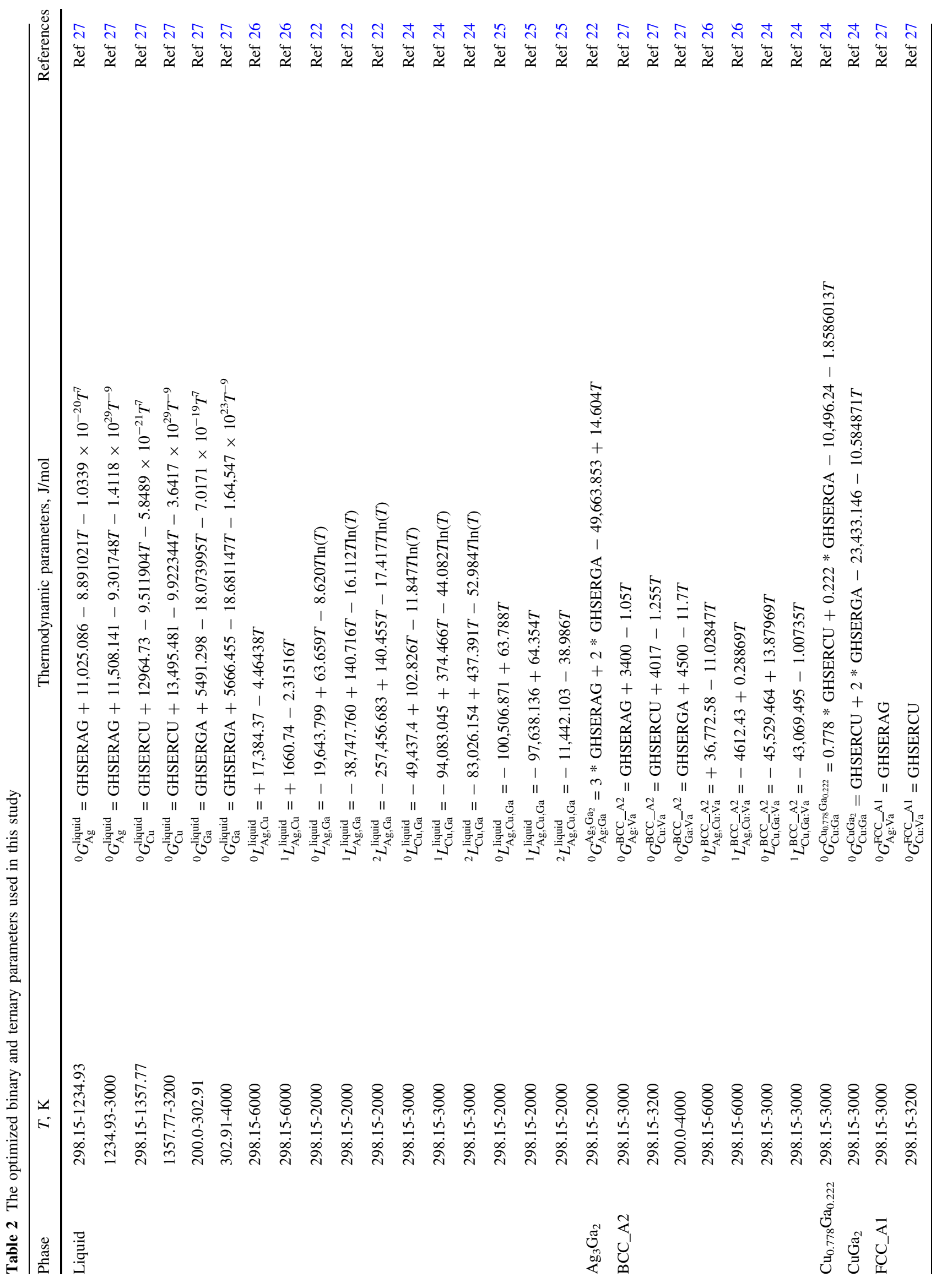


त) 崩

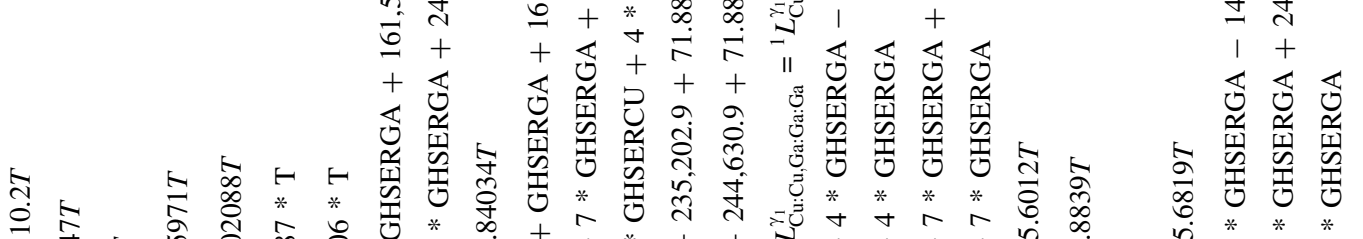

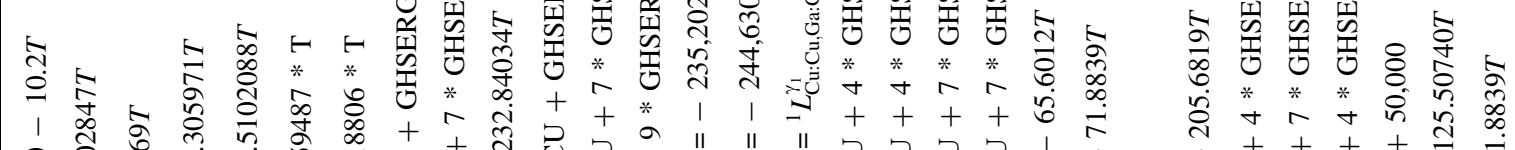

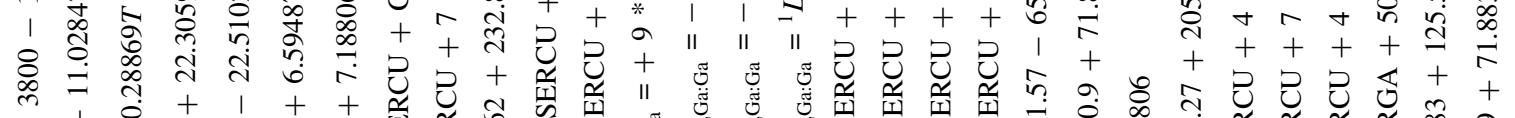

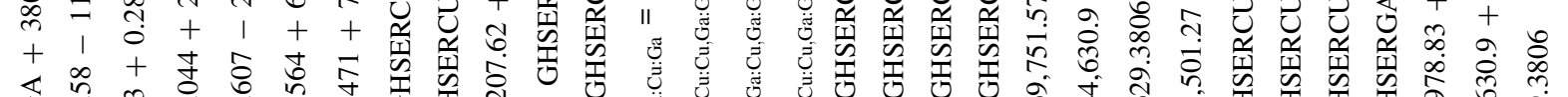

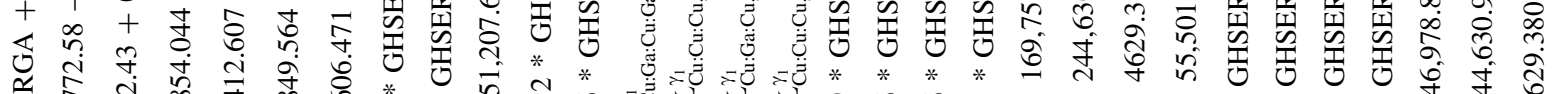

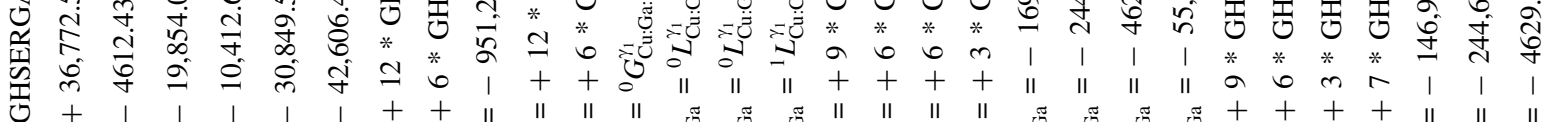

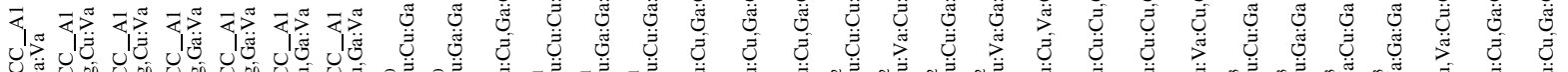

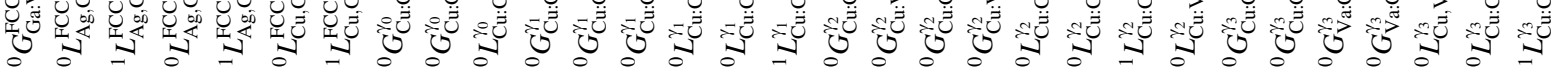

\& \& \& \& \& \& \& \& \& \& \& \& \& \& \& \& \&

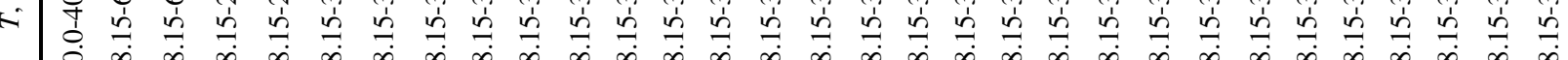
ठ্ণ 


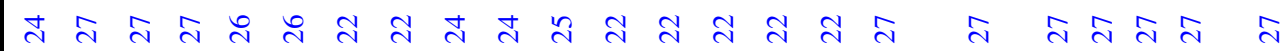

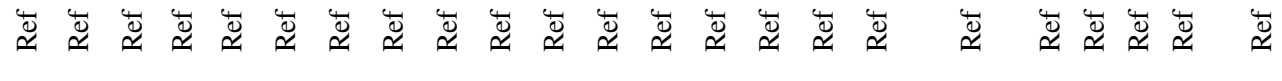

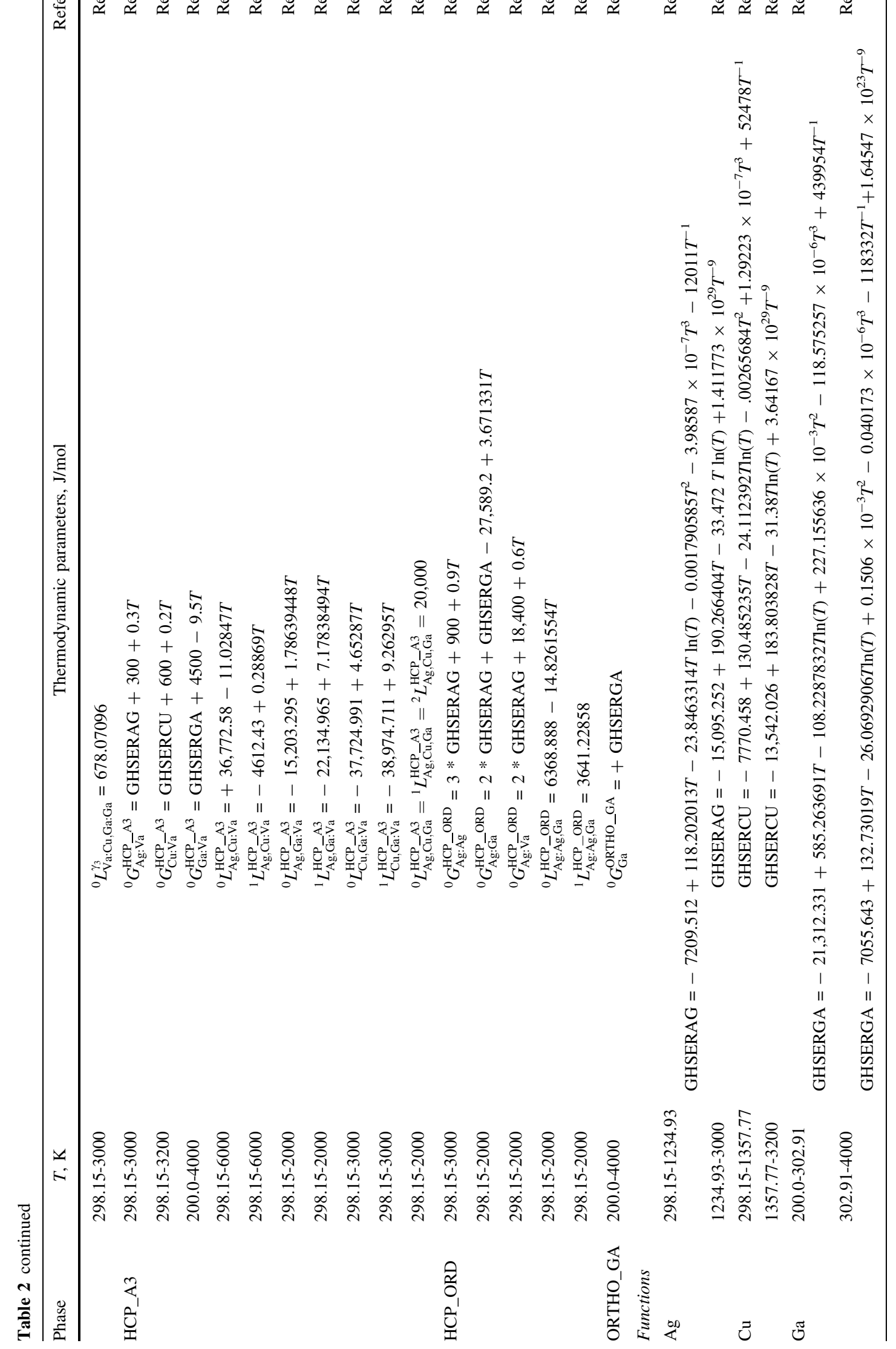


Table 3 Summary of measured thermal effects

\begin{tabular}{|c|c|c|c|c|c|c|c|}
\hline \multirow[t]{3}{*}{ Sample composition } & \multicolumn{7}{|c|}{ Temperatures of phase transformation, ${ }^{\circ} \mathrm{C}$} \\
\hline & \multicolumn{4}{|c|}{ Reaction (calculated temperature) } & \multirow[t]{2}{*}{ Other transformation } & \multicolumn{2}{|c|}{ Liquidus } \\
\hline & $*(240)$ & $* *(294)$ & $* * *(405)$ & $* * * *(496)$ & & Heating & Cooling \\
\hline \multicolumn{8}{|l|}{$x_{\mathrm{Ag}} / x_{\mathrm{Cu}}=1: 1$} \\
\hline 0.3 & & & & & $431,552,567$ & 646 & 634 \\
\hline 0.4 & 245 & 311 & 406 & & & 563 & 554 \\
\hline 0.5 & 249 & 309 & & & 393 & 512 & 487 \\
\hline 0.6 & 255 & 310 & & & 344 & 457 & 458 \\
\hline 0.7 & 253 & 307 & & & & 367 & 347 \\
\hline 0.8 & 246 & & & & & 312 & 301 \\
\hline \multicolumn{8}{|l|}{$x_{\mathrm{Ag}} / x_{\mathrm{Ga}}=1: 1$} \\
\hline 0.1 & 247 & 311 & 406 & & & 442 & 436 \\
\hline 0.2 & 249 & 313 & 408 & & & 494 & 486 \\
\hline 0.3 & & & 401 & & 512,541 & 595 & 583 \\
\hline 0.4 & & & & & $244,311,408$ & 633 & 619 \\
\hline 0.5 & & & & & $524,630,679$ & 705 & 698 \\
\hline 0.6 & & & & 497 & 581,661 & 765 & 768 \\
\hline 0.7 & & & & & 727 & 898 & 890 \\
\hline 0.8 & & & & & 724 & 923 & 875 \\
\hline
\end{tabular}

$* \mathrm{~L}+\gamma_{3} \rightarrow \mathrm{Ag}_{3} \mathrm{Ga}_{2}+\mathrm{CuGa}_{2}$

$* * \mathrm{~L}+\zeta^{\prime}-\mathrm{Ag}_{2} \mathrm{Ga} \rightarrow \mathrm{Ag}_{3} \mathrm{Ga}_{2}+\gamma_{3}$

$* * * \mathrm{~L}+\gamma_{1} \rightarrow \zeta^{\prime}-\mathrm{Ag}_{2} \mathrm{Ga}+\gamma_{2}$

$* * * * \gamma_{0} \rightarrow \gamma_{1}$

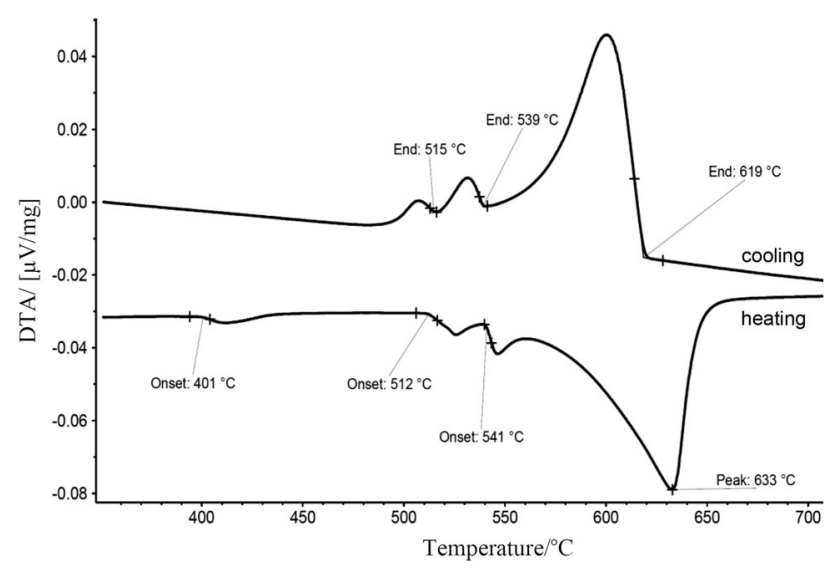

Fig. 1 Example of DTA heating and cooling curves $(10 \% \mathrm{~min})$ of the sample with the chosen $\mathrm{Ag}_{30} \mathrm{Cu}_{40} \mathrm{Ga}_{30}$ composition

gallium equal to 0.6 and 0.7 , the obtained temperature of this invariant reaction is higher than that obtained for other samples as well as the calculated value. Next, the temperature of the invariant reaction $\mathrm{L}+\zeta^{\prime}-\mathrm{Ag}_{2} \mathrm{Ga} \rightarrow \mathrm{Ag}_{3}$ $\mathrm{Ga}_{2}+\gamma_{3}$ was determined in six samples (four samples from the cross-section where $x_{\mathrm{Ag}} / x_{\mathrm{Cu}}=1: 1$, and two samples from the cross-section where $x_{\mathrm{Ag}} / x_{\mathrm{Ga}}=1: 1$ ), and it was done in the range from 307 to $313^{\circ} \mathrm{C}$. The difference between experimental values for this invariant reaction is $6{ }^{\circ} \mathrm{C}$ which is a very good result. In turn, the calculated temperature of this invariant reaction is $294{ }^{\circ} \mathrm{C}$. The lowest temperature of this invariant reaction determined experimentally is for the sample taken the from cross-section $x_{\mathrm{Ag}} /$ $x_{\mathrm{Cu}}=1: 1$ where gallium concentration is equal to 0.7 . Similarly, the temperature of invariant reaction $\mathrm{L}+\gamma_{1}$ $\rightarrow \zeta^{\prime}-\mathrm{Ag}_{2} \mathrm{Ga}+\gamma_{2}$ was determined from the analysis of four samples (one sample from the cross-section where $x_{\mathrm{Ag}} /$ $x_{\mathrm{Cu}}=1: 1$, and three samples from the cross-section where $\left.x_{\mathrm{Ag}} / x_{\mathrm{Ga}}=1: 1\right)$ in the temperature interval from 401 to $408{ }^{\circ} \mathrm{C}$. The lowest temperature of this invariant reaction is found for the sample from the cross-section $x_{\mathrm{Ag}} / x_{\mathrm{Ga}}=1: 1$ where gallium concentration is equal to 0.3 . The calculated temperature of this invariant is $405{ }^{\circ} \mathrm{C}$. The temperature of $\gamma_{0} \rightarrow \gamma_{1}$ invariant reaction was obtained by analysis of only one sample taken from cross-section $x_{\mathrm{Ag}} / x_{\mathrm{Ga}}=1: 1$ where concentration of copper equals 0.6 . The obtained value is $497{ }^{\circ} \mathrm{C}$ while the calculated temperature of this invariant reaction is $496{ }^{\circ} \mathrm{C}$. Additionally, in Table 3 liquidus temperatures from heating and cooling for all fourteen samples which were studied by DTA technique are 
Fig. 2 Experimental data compared with the calculation of $\mathrm{Ag}-\mathrm{Cu}-\mathrm{Ga}$ system given for isoplethal section with $x_{\mathrm{Ag}}$ / $x_{\mathrm{Cu}}=1: 1$
Fig. 3 Experimental data compared with the calculation of $\mathrm{Ag}-\mathrm{Cu}-\mathrm{Ga}$ system given for isoplethal section with $x_{\mathrm{Ag}}$ l $x_{\mathrm{Ga}}=1: 1$
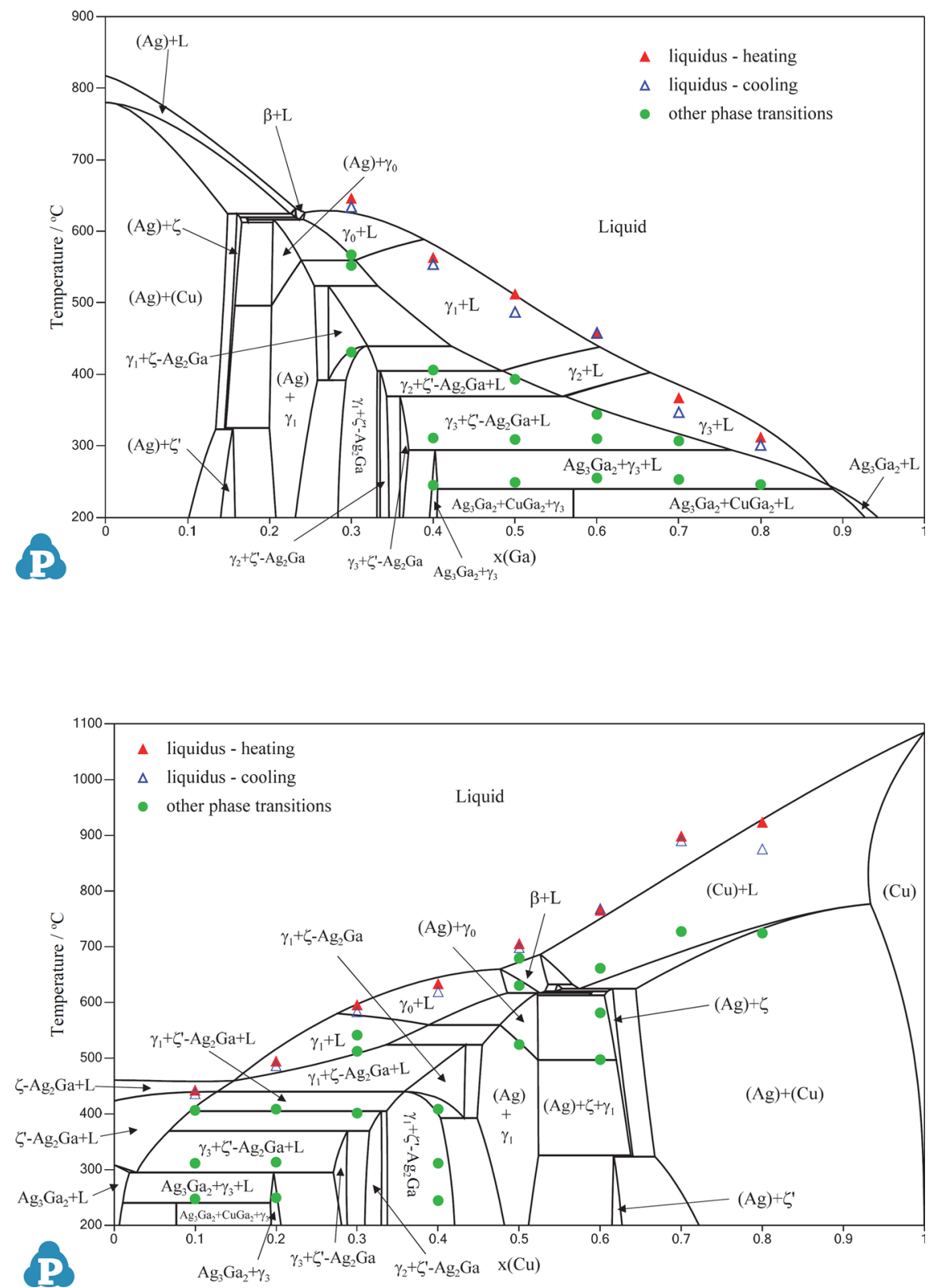

given. The results of the calculations of these two crosssections were compared with the experimental results obtained in this work and are shown in Fig. 2 and 3.

It can be seen from Fig. 2 and 3 that in the case of the above listed invariant reactions the obtained experimental results are in good agreement with the results of the thermodynamic calculation. The biggest difference between invariant temperature obtained from the experimental results and the calculation is $19^{\circ} \mathrm{C}$ for the reaction $\left(\mathrm{L}+\zeta^{\prime}-\mathrm{Ag}_{2} \mathrm{Ga} \rightarrow \mathrm{Ag}_{3} \mathrm{Ga}_{2}+\gamma_{3}\right)$. In the case of liquidus temperatures which were determined in the present work, the experimental values are in good agreement with the results of calculation as in the case of listed invariant reactions. The biggest difference between temperatures of liquidus obtained from the experimental results and the calculation is found for the sample from cross-section $x_{\mathrm{Ag}} /$ $x_{\mathrm{Ga}}=1: 1$, where gallium concentration is equal to 0.7 . The obtained value is $898^{\circ} \mathrm{C}$ while the calculated temperature of this invariant reaction is $842{ }^{\circ} \mathrm{C}$. However, in the case of other samples the difference between liquidus temperature obtained from the experimental results and the calculation is about $20^{\circ} \mathrm{C}$. 


\subsection{Phase Equilibria in the Ag-Cu-Ga Ternary System}

For the experimental investigations of the equilibrium between phases present in the ternary Ag-Cu-Ga system at three chosen temperatures, 30 different alloy compositions were prepared. All samples were investigated with SEM/ EDS and XRD analysis. According to the present results, no ternary compounds have been found in the $\mathrm{Ag}-\mathrm{Cu}-\mathrm{Ga}$ system. Only binary and unary phases exist in this system.

As a result of the EDS analysis of phase compositions, the following phases have been determined, namely: (Ag), $(\mathrm{Cu}), \zeta^{\prime}-\mathrm{Ag}_{2} \mathrm{Ga}, \zeta-\mathrm{Ag}_{2} \mathrm{Ga}, \mathrm{Ag}_{3} \mathrm{Ga}_{2}, \zeta^{\prime}, \gamma_{0}, \gamma_{1}, \gamma_{2}, \gamma_{3}, \mathrm{CuGa}_{2}$ and the liquid. Based on analysis of all microstructures of ternary alloys which were investigated, one phase is observed in four samples, i.e. no 22 and 28-30. The twophase equilibria were observed in sixteen samples: 1-2,
8-10, 12-13, 16-18 and 24-25. Three-phase equilibria were found in ten samples i.e. no 4-7, 11, 14-15, 19, 21 and 25. The microstructures of the chosen alloys: $6,9,19,21,26$ and 28 are shown in Fig. 4.

As shown in Fig. 4 two-phase equilibrium is observed in the microstructures of samples no 9 and 26. Three-phase equilibrium is observed in samples: 6,19 and 21. Finally, single phase is observed in sample no. 28. Three phases: $\zeta$ $\mathrm{Ag}_{2} \mathrm{Ga}, \zeta^{\prime}-\mathrm{Ag}_{2} \mathrm{Ga},(\mathrm{Ag})$ are detected as light grey fields which were observed in the microstructures of samples: 6 , $9,19,21$ and 26. The detected solubility of Ga is as follows: in $\zeta-\mathrm{Ag}_{2} \mathrm{Ga}$ phase it is 29.9 at.\% (sample 21) and in $\zeta^{\prime}-\mathrm{Ag}_{2} \mathrm{Ga}$ phase it is 27.4 at.\% (sample 9). The solubility of $\mathrm{Ga}$ in (Ag) phase is 7.9 at.\% (sample 6), 8.8 at.\% (sample 19 ) and 6.3 at.\% (sample 26). The $\gamma_{1}$ phase is detected as a dark grey field and it is observed in the microstructures of samples no. 6, 9, 19 and 21. The detected solubility of Ga
Fig. 4 SEM micrographs (BSE mode) of the six selected alloy samples annealed at $200{ }^{\circ} \mathrm{C}$ (samples 6 and 9), $450{ }^{\circ} \mathrm{C}$ (samples 19 and 21) and $650{ }^{\circ} \mathrm{C}$ (samples 26 and 28)
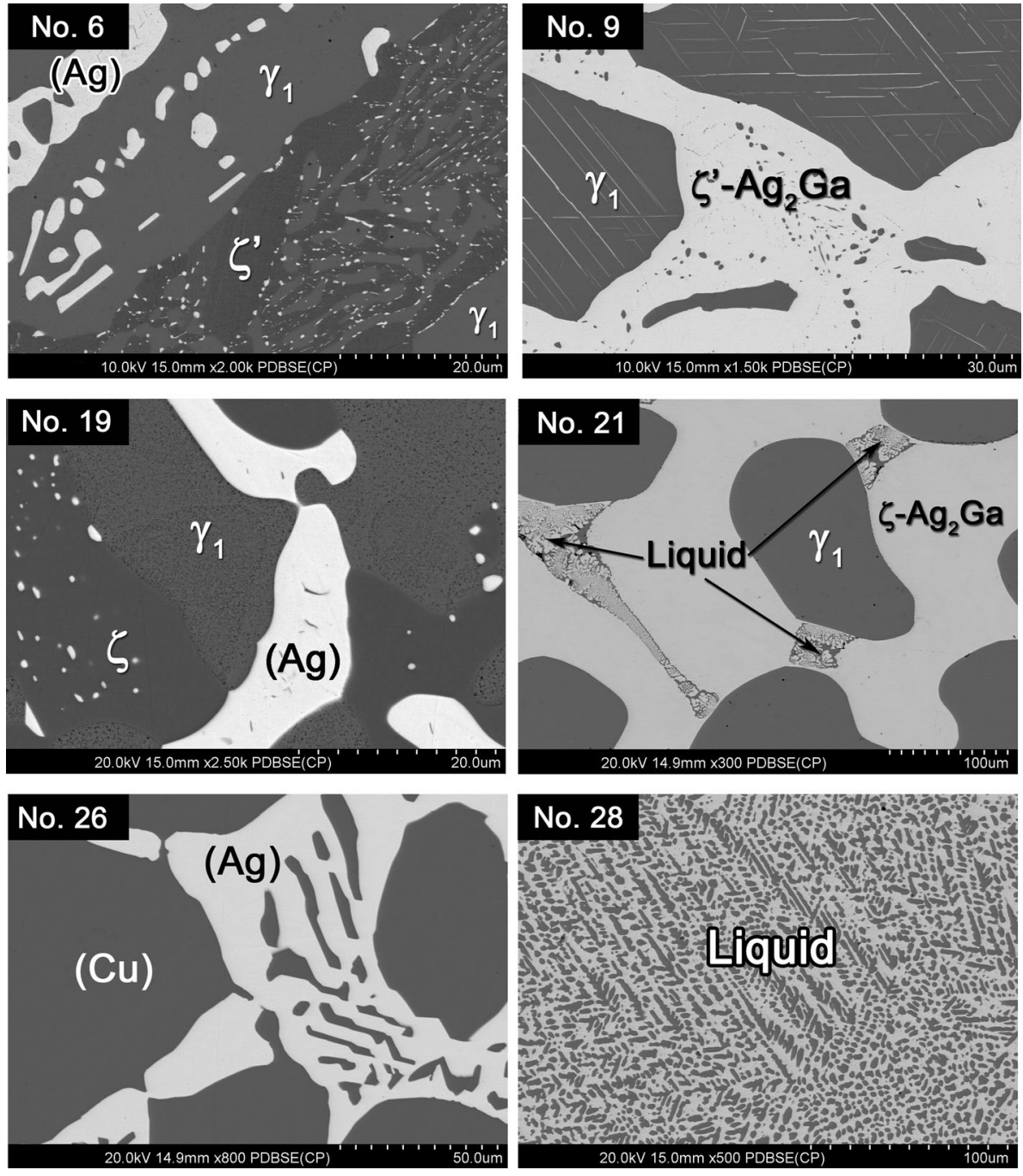

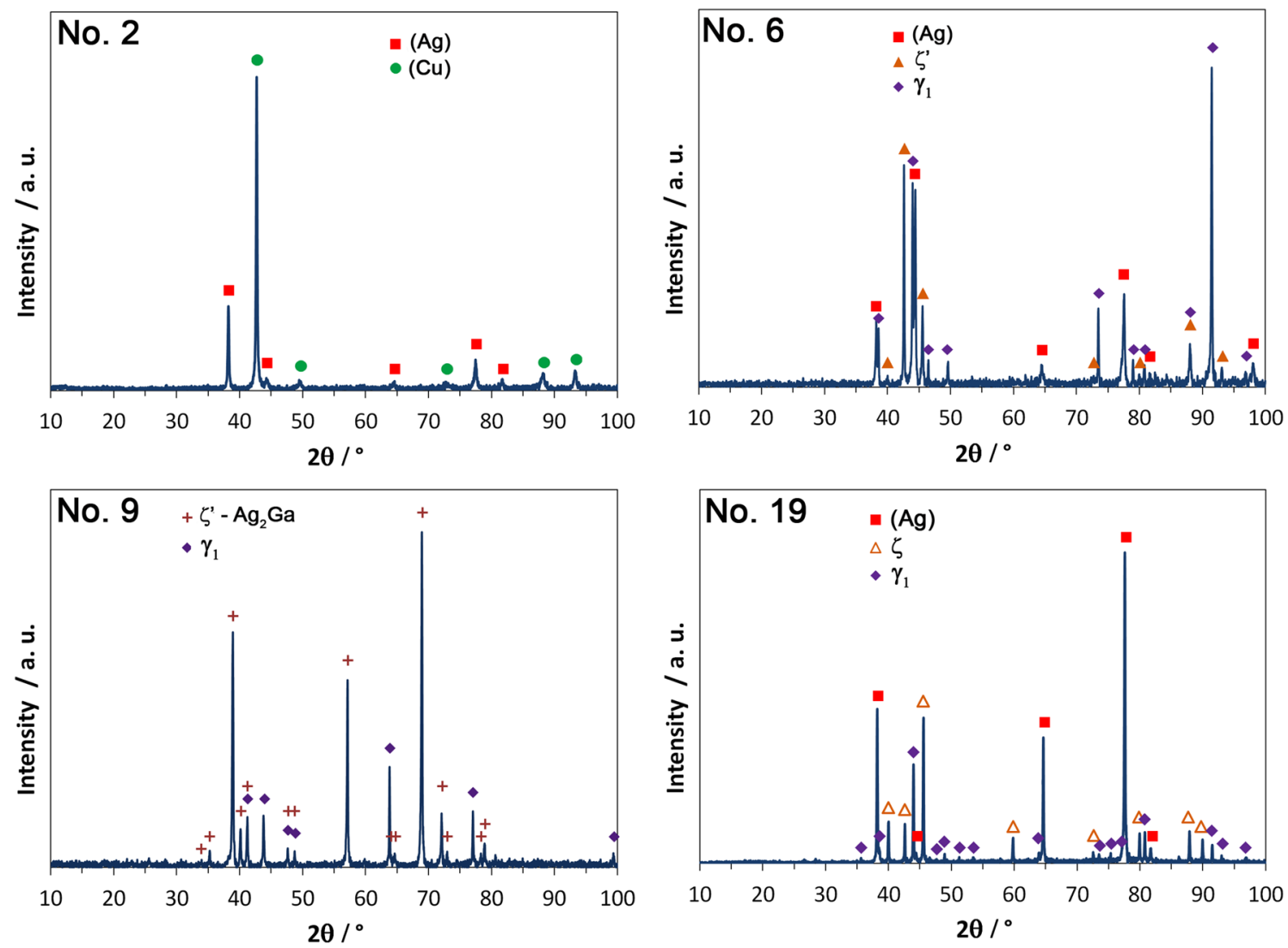

Fig. 5 XRD spectra of the selected alloy samples annealed at $200{ }^{\circ} \mathrm{C}$ (samples 2, 6 and 9) and $450{ }^{\circ} \mathrm{C}$ (sample 19)

in $\gamma_{1}$ phase is 29.8 at.\% (sample 6), 31.5 at.\% (sample 9), 28.5 at.\% (sample 19) and 34.1 at.\% (sample 21). The $\zeta$ and $\zeta^{\prime}$ phases are detected as dark grey fields with bright precipitations of $(\mathrm{Ag})$ phase. These phases were observed in the microstructures of two samples i.e. no 6 and 19. The solubility of $\mathrm{Ga}$ in $\zeta$ phase is 21.0 at.\% (sample 19) and in $\zeta^{\prime}$ phase is 21.6 at.\% (sample 6). (Cu) phase with the solubility of Ga equal to 16.0 at.\% was detected as a dark field in the microstructure of sample 26. Liquid phase with the $\mathrm{Ag}_{40.3} \mathrm{Cu}_{17.6} \mathrm{Ga}_{42.1}$ composition, which is trapped in $\zeta$ $\mathrm{Ag}_{2} \mathrm{Ga}$ phase, was detected in the microstructure of sample 21. Microstructural investigation of sample 28 revealed only one phase, which was liquid, with the $\mathrm{Ag}_{33.1} \mathrm{Cu}_{33.9}$ $\mathrm{Ga}_{32.9}$ composition. The results of the scanning electron microscopy are also confirmed by the XRD analysis. In Fig. 5 XRD spectra of chosen ternary Ag-Cu-Ga alloys are shown.

The results of the composition and phase analyses based on SEM/EDS and XRD data obtained for samples annealed at 200, 450 and $650{ }^{\circ} \mathrm{C}$ are summarized in Table 4. Experimentally determined deviations in chemical composition of the phases are also given in this table.

\subsection{Isothermal Sections}

The calculated isothermal section at $200{ }^{\circ} \mathrm{C}$ is compared with the experimental results obtained in this work and it is shown in Fig. 6. On the basis of the results presented in Table 4 , the following fields of coexisting phases are determined: five three-phase regions: $\left[(\mathrm{Ag})+(\mathrm{Cu})+\zeta^{\prime}\right.$, $(\mathrm{Ag})+\zeta^{\prime}-\mathrm{Ag}_{2} \mathrm{Ga}+\gamma_{1},(\mathrm{Ag})+\zeta^{\prime}+\gamma_{1}, \quad \zeta^{\prime}-\mathrm{Ag}_{2} \mathrm{Ga}+\gamma_{2-}$ $+\gamma_{3}$ and $\left.\mathrm{Ag}_{3} \mathrm{Ga}_{2}+\gamma_{3}+\mathrm{CuGa}_{2}\right]$, and four two-phase regions: $\quad\left[(\mathrm{Ag})+(\mathrm{Cu}), \quad(\mathrm{Ag})+\zeta^{\prime}, \quad(\mathrm{Ag})+\gamma_{1}\right.$, $\left.\mathrm{Ag}_{3} \mathrm{Ga}_{2}+\gamma_{3}\right]$.

Increasing the temperature up to $450{ }^{\circ} \mathrm{C}$ brings about the formation of the liquid phase. The comparison of calculation with the experimental results is shown in Fig. 7. On the basis of the results gathered in Table 4, the following fields are determined: two three-phase regions: $\left[(\mathrm{Ag})+\zeta+\gamma_{1}, \zeta-\mathrm{Ag}_{2} \mathrm{Ga}+\gamma 1+\right.$ liquid $]$, four two-phase regions: $\left[(\mathrm{Ag})+(\mathrm{Cu}),(\mathrm{Ag})+\gamma_{1}, \quad \zeta-\mathrm{Ag}_{2} \mathrm{Ga}+\gamma_{1}, \quad \gamma_{2-}\right.$ + liquid], and one-phase field corresponding to the liquid.

Finally, the predicted isothermal section at $650{ }^{\circ} \mathrm{C}$ is compared with the experimental results of this work in Fig. 8. The following fields can be observed: one threephase region $(\mathrm{Ag})+(\mathrm{Cu})+$ liquid, two two-phase 
Table 4 Experimentally determined phase compositions in the ternary Ag-Cu-Ga system

\begin{tabular}{|c|c|c|c|c|c|c|c|c|}
\hline \multirow[t]{2}{*}{ Alloy no. } & \multirow{2}{*}{$\begin{array}{c}\text { Nominal } \\
\text { composition, } \\
\text { at. } \%\end{array}$} & \multirow[t]{2}{*}{$\begin{array}{l}\text { Anneal. } \\
\text { temp., }{ }^{\circ} \mathrm{C}\end{array}$} & \multirow[t]{2}{*}{$\begin{array}{l}\text { Theor. predicted } \\
\text { phases }\end{array}$} & \multicolumn{2}{|c|}{ Experimentally determined phases } & \multicolumn{3}{|c|}{$\begin{array}{c}\text { Phase composition } \\
\text { determined by EDS, at.\% }\end{array}$} \\
\hline & & & & XRD & SEM-EDS & $\mathrm{Ag}$ & $\mathrm{Cu}$ & $\mathrm{Ga}$ \\
\hline \multirow[t]{2}{*}{1} & $\mathrm{Ag}_{45} \mathrm{Cu}_{45} \mathrm{Ga}_{10}$ & 200 & $(\mathrm{Ag})$ & $(\mathrm{Ag})$ & $(\mathrm{Ag})$ & $96.5 \pm 0.3$ & $\ldots$ & $3.5 \pm 0.3$ \\
\hline & & & $(\mathrm{Cu})$ & $(\mathrm{Cu})$ & $(\mathrm{Cu})$ & $\cdots$ & $84.4 \pm 0.3$ & $15.6 \pm 0.3$ \\
\hline \multirow[t]{2}{*}{2} & $\mathrm{Ag}_{10} \mathrm{Cu}_{80} \mathrm{Ga}_{10}$ & 200 & $(\mathrm{Ag})$ & $(\mathrm{Ag})$ & $(\mathrm{Ag})$ & $99.5 \pm 0.1$ & $\ldots$ & $0.5 \pm 0.1$ \\
\hline & & & $(\mathrm{Cu})$ & $(\mathrm{Cu})$ & $(\mathrm{Cu})$ & $\cdots$ & $88.3 \pm 0.3$ & $11.7 \pm 0.3$ \\
\hline \multirow[t]{2}{*}{3} & $\mathrm{Ag}_{42.5} \mathrm{Cu}_{42.5} \mathrm{Ga}_{15}$ & 200 & $(\mathrm{Ag})$ & $(\mathrm{Ag})$ & $(\mathrm{Ag})$ & $94.2 \pm 0.4$ & $\ldots$ & $5.8 \pm 0.4$ \\
\hline & & & $\zeta^{\prime}$ & $\zeta^{\prime}$ & $\zeta^{\prime}$ & $\ldots$ & $77.8 \pm 0.2$ & $22.2 \pm 0.2$ \\
\hline \multirow[t]{3}{*}{4} & $\mathrm{Ag}_{15} \mathrm{Cu}_{70} \mathrm{Ga}_{15}$ & 200 & $(\mathrm{Ag})$ & $(\mathrm{Ag})$ & $(\mathrm{Ag})$ & $96.2 \pm 0.3$ & $\ldots$ & $3.8 \pm 0.3$ \\
\hline & & & $(\mathrm{Cu})$ & $(\mathrm{Cu})$ & $(\mathrm{Cu})$ & $\ldots$ & $84.4 \pm 0.2$ & $15.6 \pm 0.2$ \\
\hline & & & $\zeta^{\prime}$ & $\zeta^{\prime}$ & $\zeta^{\prime}$ & $\ldots$ & $77.8 \pm 0.2$ & $22.2 \pm 0.2$ \\
\hline \multirow[t]{3}{*}{5} & $\mathrm{Ag}_{60} \mathrm{Cu}_{20} \mathrm{Ga}_{20}$ & 200 & $(\mathrm{Ag})$ & $(\mathrm{Ag})$ & $(\mathrm{Ag})$ & $87.7 \pm 0.5$ & $\ldots$ & $12.3 \pm 0.5$ \\
\hline & & & $\zeta^{\prime}-\mathrm{Ag}_{2} \mathrm{Ga}$ & $\zeta^{\prime}-\mathrm{Ag}_{2} \mathrm{Ga}$ & $\zeta^{\prime}-\mathrm{Ag}_{2} \mathrm{Ga}$ & $75.2 \pm 0.4$ & $\ldots$ & $24.8 \pm 0.4$ \\
\hline & & & $\gamma_{1}$ & $\gamma_{1}$ & $\gamma_{1}$ & $\ldots$ & $68.4 \pm 0.3$ & $31.6 \pm 0.3$ \\
\hline \multirow[t]{3}{*}{6} & $\mathrm{Ag}_{40} \mathrm{Cu}_{40} \mathrm{Ga}_{20}$ & 200 & $(\mathrm{Ag})$ & $(\mathrm{Ag})$ & $(\mathrm{Ag})$ & $92.1 \pm 0.9$ & $\ldots$ & $7.9 \pm 0.9$ \\
\hline & & & $\zeta^{\prime}$ & $\zeta^{\prime}$ & $\zeta^{\prime}$ & $\ldots$ & $78.4 \pm 0.3$ & $21.6 \pm 0.3$ \\
\hline & & & $\gamma_{1}$ & $\gamma_{1}$ & $\gamma_{1}$ & $\ldots$ & $70.2 \pm 0.4$ & $29.8 \pm 0.4$ \\
\hline \multirow[t]{3}{*}{7} & $\mathrm{Ag}_{20} \mathrm{Cu}_{60} \mathrm{Ga}_{20}$ & 200 & $(\mathrm{Ag})$ & $(\mathrm{Ag})$ & $(\mathrm{Ag})$ & $92.0 \pm 0.8$ & $\ldots$ & $8.0 \pm 0.8$ \\
\hline & & & $\zeta^{\prime}$ & $\zeta^{\prime}$ & $\zeta^{\prime}$ & $\ldots$ & $78.0 \pm 0.4$ & $22.0 \pm 0.4$ \\
\hline & & & $\gamma_{1}$ & $\gamma_{1}$ & $\gamma_{1}$ & $\ldots$ & $70.2 \pm 0.2$ & $29.8 \pm 0.2$ \\
\hline \multirow[t]{2}{*}{8} & $\mathrm{Ag}_{25} \mathrm{Cu}_{50} \mathrm{Ga}_{25}$ & 200 & $(\mathrm{Ag})$ & $(\mathrm{Ag})$ & $(\mathrm{Ag})$ & $90.1 \pm 0.4$ & $\ldots$ & $9.9 \pm 0.4$ \\
\hline & & & $\gamma_{1}$ & $\gamma_{1}$ & $\gamma_{1}$ & $\ldots$ & $69.0 \pm 0.1$ & $31.0 \pm 0.1$ \\
\hline \multirow[t]{2}{*}{9} & $\mathrm{Ag}_{35} \mathrm{Cu}_{35} \mathrm{Ga}_{30}$ & 200 & $\zeta^{\prime}-\mathrm{Ag}_{2} \mathrm{Ga}$ & $\zeta^{\prime}-\mathrm{Ag}_{2} \mathrm{Ga}$ & $\zeta^{\prime}-\mathrm{Ag}_{2} \mathrm{Ga}$ & $72.6 \pm 0.3$ & $\ldots$ & $27.4 \pm 0.3$ \\
\hline & & & $\gamma_{1}$ & $\gamma_{1}$ & $\gamma_{1}$ & $\ldots$ & $68.5 \pm 0.3$ & $31.5 \pm 0.3$ \\
\hline \multirow[t]{2}{*}{10} & $\mathrm{Ag}_{30} \mathrm{Cu}_{40} \mathrm{Ga}_{30}$ & 200 & $\zeta^{\prime}-\mathrm{Ag}_{2} \mathrm{Ga}$ & $\zeta^{\prime}-\mathrm{Ag}_{2} \mathrm{Ga}$ & $\zeta^{\prime}-\mathrm{Ag}_{2} \mathrm{Ga}$ & $73.3 \pm 0.3$ & $\ldots$ & $26.7 \pm 0.3$ \\
\hline & & & $\gamma_{1}$ & $\gamma_{1}$ & $\gamma_{1}$ & $\ldots$ & $68.8 \pm 0.8$ & $31.2 \pm 0.8$ \\
\hline \multirow[t]{3}{*}{11} & $\mathrm{Ag}_{35} \mathrm{Cu}_{30} \mathrm{Ga}_{35}$ & 200 & $\zeta^{\prime}-\mathrm{Ag}_{2} \mathrm{Ga}$ & $\zeta^{\prime}-\mathrm{Ag}_{2} \mathrm{Ga}$ & $\zeta^{\prime}-\mathrm{Ag}_{2} \mathrm{Ga}$ & $67.8 \pm 0.4$ & $\ldots$ & $32.2 \pm 0.4$ \\
\hline & & & $\gamma_{2}$ & $\gamma_{2}$ & $\gamma_{2}$ & $\ldots$ & $64.1 \pm 0.6$ & $35.9 \pm 0.6$ \\
\hline & & & $\gamma_{3}$ & $\gamma_{3}$ & $\gamma_{3}$ & $\ldots$ & $61.5 \pm 0.4$ & $38.5 \pm 0.4$ \\
\hline \multirow[t]{2}{*}{12} & $\mathrm{Ag}_{40} \mathrm{Cu}_{20} \mathrm{Ga}_{40}$ & 200 & $\mathrm{Ag}_{3} \mathrm{Ga}_{2}$ & $\mathrm{Ag}_{3} \mathrm{Ga}_{2}$ & $\mathrm{Ag}_{3} \mathrm{Ga}_{2}$ & $60.8 \pm 0.5$ & $\ldots$ & $39.2 \pm 0.5$ \\
\hline & & & $\gamma_{3}$ & $\gamma_{3}$ & $\gamma_{3}$ & $\ldots$ & $60.2 \pm 0.6$ & $39.8 \pm 0.6$ \\
\hline \multirow[t]{2}{*}{13} & $\mathrm{Ag}_{30} \mathrm{Cu}_{30} \mathrm{Ga}_{40}$ & 200 & $\mathrm{Ag}_{3} \mathrm{Ga}_{2}$ & $\mathrm{Ag}_{3} \mathrm{Ga}_{2}$ & $\mathrm{Ag}_{3} \mathrm{Ga}_{2}$ & $60.4 \pm 0.6$ & $\ldots$ & $39.6 \pm 0.6$ \\
\hline & & & $\gamma_{3}$ & $\gamma_{3}$ & $\gamma_{3}$ & $\ldots$ & $59.7 \pm 0.4$ & $40.3 \pm 0.4$ \\
\hline \multirow[t]{3}{*}{14} & $\mathrm{Ag}_{45} \mathrm{Cu}_{10} \mathrm{Ga}_{45}$ & 200 & $\mathrm{Ag}_{3} \mathrm{Ga}_{2}$ & $\mathrm{Ag}_{3} \mathrm{Ga}_{2}$ & $\mathrm{Ag}_{3} \mathrm{Ga}_{2}$ & $59.5 \pm 0.8$ & $\ldots$ & $40.5 \pm 0.8$ \\
\hline & & & $\gamma_{3}$ & $\gamma_{3}$ & $\gamma_{3}$ & $\ldots$ & $59.0 \pm 0.5$ & $41.0 \pm 0.5$ \\
\hline & & & $\mathrm{CuGa}_{2}$ & $\mathrm{CuGa}_{2}$ & $\mathrm{CuGa}_{2}$ & $\ldots$ & $34.2 \pm 0.6$ & $65.8 \pm 0.6$ \\
\hline \multirow[t]{3}{*}{15} & $\mathrm{Ag}_{25} \mathrm{Cu}_{25} \mathrm{Ga}_{50}$ & 200 & $\mathrm{Ag}_{3} \mathrm{Ga}_{2}$ & $\mathrm{Ag}_{3} \mathrm{Ga}_{2}$ & $\mathrm{Ag}_{3} \mathrm{Ga}_{2}$ & $60.2 \pm 0.4$ & $\ldots$ & $39.8 \pm 0.4$ \\
\hline & & & $\gamma_{3}$ & $\gamma_{3}$ & $\gamma_{3}$ & $\ldots$ & $59.7 \pm 0.8$ & $40.3 \pm 0.8$ \\
\hline & & & $\mathrm{CuGa}_{2}$ & $\mathrm{CuGa}_{2}$ & $\mathrm{CuGa}_{2}$ & $\ldots$ & $33.2 \pm 0.3$ & $66.8 \pm 0.3$ \\
\hline 16 & $\mathrm{Ag}_{45} \mathrm{Cu}_{45} \mathrm{Ga}_{10}$ & 450 & $(\mathrm{Ag})$ & $(\mathrm{Ag})$ & $(\mathrm{Ag})$ & $94.5 \pm 0.3$ & $1.0 \pm 0.3$ & $4.5 \pm 0.3$ \\
\hline & & & $(\mathrm{Cu})$ & $(\mathrm{Cu})$ & $(\mathrm{Cu})$ & $\ldots$ & $85.1 \pm 0.4$ & $14.9 \pm 0.4$ \\
\hline 17 & $\mathrm{Ag}_{15} \mathrm{Cu}_{70} \mathrm{Ga}_{15}$ & 450 & $(\mathrm{Ag})$ & $(\mathrm{Ag})$ & $(\mathrm{Ag})$ & $92.1 \pm 0.4$ & $1.0 \pm 0.4$ & $6.9 \pm 0.4$ \\
\hline & & & $(\mathrm{Cu})$ & $(\mathrm{Cu})$ & $(\mathrm{Cu})$ & $\ldots$ & $83.0 \pm 0.3$ & $17.0 \pm 0.3$ \\
\hline 18 & $\mathrm{Ag}_{60} \mathrm{Cu}_{20} \mathrm{Ga}_{20}$ & 450 & $(\mathrm{Ag})$ & $(\mathrm{Ag})$ & $(\mathrm{Ag})$ & $84.2 \pm 0.3$ & $0.6 \pm 0.3$ & $15.2 \pm 0.3$ \\
\hline & & & $\gamma_{1}$ & $\gamma_{1}$ & $\gamma_{1}$ & $\ldots$ & $68.1 \pm 0.5$ & $31.9 \pm 0.5$ \\
\hline 19 & $\mathrm{Ag}_{20} \mathrm{Cu}_{60} \mathrm{Ga}_{20}$ & 450 & $(\mathrm{Ag})$ & $(\mathrm{Ag})$ & $(\mathrm{Ag})$ & $90 \pm 0.4$ & $1.2 \pm 0.4$ & $8.8 \pm 0.4$ \\
\hline & & & $\zeta$ & $\zeta$ & $\zeta$ & $\ldots$ & $79.0 \pm 0.3$ & $21.0 \pm 0.3$ \\
\hline & & & $\gamma_{1}$ & $\gamma_{1}$ & $\gamma_{1}$ & $\ldots$ & $71.5 \pm 0.6$ & $28.5 \pm 0.6$ \\
\hline
\end{tabular}


Table 4 continued

\begin{tabular}{|c|c|c|c|c|c|c|c|c|}
\hline \multirow[t]{2}{*}{ Alloy no. } & \multirow{2}{*}{$\begin{array}{c}\text { Nominal } \\
\text { composition, } \\
\text { at. } \%\end{array}$} & \multirow[t]{2}{*}{$\begin{array}{l}\text { Anneal. } \\
\text { temp., }{ }^{\circ} \mathrm{C}\end{array}$} & \multirow[t]{2}{*}{$\begin{array}{c}\text { Theor. predicted } \\
\text { phases }\end{array}$} & \multicolumn{2}{|c|}{ Experimentally determined phases } & \multicolumn{3}{|c|}{$\begin{array}{c}\text { Phase composition } \\
\text { determined by EDS, at.\% }\end{array}$} \\
\hline & & & & XRD & SEM-EDS & $\mathrm{Ag}$ & $\mathrm{Cu}$ & $\mathrm{Ga}$ \\
\hline \multirow[t]{2}{*}{20} & $\mathrm{Ag}_{30} \mathrm{Cu}_{40} \mathrm{Ga}_{30}$ & 450 & $\zeta-\mathrm{Ag}_{2} \mathrm{Ga}$ & $\zeta-\mathrm{Ag}_{2} \mathrm{Ga}$ & $\zeta-\mathrm{Ag}_{2} \mathrm{Ga}$ & $75 \pm 0.6$ & $\ldots$ & $25 \pm 0.6$ \\
\hline & & & $\gamma_{1}$ & $\gamma_{1}$ & $\gamma_{1}$ & $\ldots$ & $66.3 \pm 0.4$ & $33.7 \pm 0.4$ \\
\hline \multirow[t]{3}{*}{21} & $\mathrm{Ag}_{33.3} \mathrm{Cu}_{33.3} \mathrm{Ga}_{33.4}$ & 450 & $\zeta-\mathrm{Ag}_{2} \mathrm{Ga}$ & $\zeta-\mathrm{Ag}_{2} \mathrm{Ga}$ & $\zeta-\mathrm{Ag}_{2} \mathrm{Ga}$ & $70.1 \pm 0.4$ & $\ldots$ & $29.9 \pm 0.4$ \\
\hline & & & $\gamma_{1}$ & $\gamma_{1}$ & $\gamma_{1}$ & $\ldots$ & $65.9 \pm 0.2$ & $34.1 \pm 0.2$ \\
\hline & & & & & Liquid & $40.3 \pm 2.1$ & $17.6 \pm 1.4$ & $42.1 \pm 2.5$ \\
\hline \multirow[t]{2}{*}{22} & $\mathrm{Ag}_{35} \mathrm{Cu}_{10} \mathrm{Ga}_{55}$ & 450 & $\gamma_{1}$ & & & $\ldots$ & $\ldots$ & $\cdots$ \\
\hline & & & Liquid & & Liquid & $34.5 \pm 0.8$ & $9.7 \pm 0.6$ & $55.8 \pm 1.4$ \\
\hline \multirow[t]{2}{*}{23} & $\mathrm{Ag}_{10} \mathrm{Cu}_{30} \mathrm{Ga}_{60}$ & 450 & $\gamma_{2}$ & $\gamma_{2}$ & $\gamma_{2}$ & $\ldots$ & $64.7 \pm 0.6$ & $35.3 \pm 0.6$ \\
\hline & & & Liquid & & Liquid & $11.7 \pm 0.8$ & $20.5 \pm 1.1$ & $67.8 \pm 1.7$ \\
\hline \multirow[t]{2}{*}{24} & $\mathrm{Ag}_{45} \mathrm{Cu}_{45} \mathrm{Ga}_{10}$ & 650 & $(\mathrm{Ag})$ & $(\mathrm{Ag})$ & $(\mathrm{Ag})$ & $91.1 \pm 0.8$ & $4.2 \pm 0.4$ & $4.7 \pm 0.6$ \\
\hline & & & $(\mathrm{Cu})$ & $(\mathrm{Cu})$ & $(\mathrm{Cu})$ & $1.2 \pm 0.3$ & $83.8 \pm 0.7$ & $15.0 \pm 0.5$ \\
\hline \multirow[t]{3}{*}{25} & $\mathrm{Ag}_{42.5} \mathrm{Cu}_{42.5} \mathrm{Ga}_{15}$ & 650 & $(\mathrm{Ag})$ & $(\mathrm{Ag})$ & $(\mathrm{Ag})$ & $88 \pm 0.5$ & $3.5 \pm 0.3$ & $8.5 \pm 0.4$ \\
\hline & & & $(\mathrm{Cu})$ & $(\mathrm{Cu})$ & $(\mathrm{Cu})$ & $1.2 \pm 0.5$ & $80 \pm 0.8$ & $18.8 \pm 0.5$ \\
\hline & & & $\zeta$ & & Liquid & $42.9 \pm 1.0$ & $37.7 \pm 1.3$ & $19.4 \pm 0.4$ \\
\hline \multirow[t]{2}{*}{26} & $\mathrm{Ag}_{15} \mathrm{Cu}_{70} \mathrm{Ga}_{15}$ & 650 & $(\mathrm{Ag})$ & $(\mathrm{Ag})$ & $(\mathrm{Ag})$ & $89.0 \pm 0.7$ & $4.7 \pm 0.6$ & $6.3 \pm 0.2$ \\
\hline & & & $(\mathrm{Cu})$ & $(\mathrm{Cu})$ & $(\mathrm{Cu})$ & $1.5 \pm 0.4$ & $82.5 \pm 0.2$ & $16.0 \pm 0.2$ \\
\hline \multirow[t]{3}{*}{27} & $\mathrm{Ag}_{60} \mathrm{Cu}_{20} \mathrm{Ga}_{20}$ & 650 & $(\mathrm{Ag})$ & $(\mathrm{Ag})$ & $(\mathrm{Ag})$ & $86.1 \pm 0.8$ & $2.8 \pm 0.6$ & $11.1 \pm 0.9$ \\
\hline & & & $\gamma_{0}$ & & $\ldots$ & $\ldots$ & $\ldots$ & $\ldots$ \\
\hline & & & Liquid & & Liquid & $56.6 \pm 1.7$ & $23.0 \pm 0.9$ & $20.4 \pm 2.6$ \\
\hline \multirow[t]{2}{*}{28} & $\mathrm{Ag}_{33.3} \mathrm{Cu}_{33.3} \mathrm{Ga}_{33.4}$ & 650 & $\gamma_{0}$ & & $\ldots$ & $\cdots$ & $\cdots$ & $\cdots$ \\
\hline & & & Liquid & & Liquid & $33.1 \pm 0.5$ & $33.9 \pm 1.0$ & $33.0 \pm 0.5$ \\
\hline 29 & $\mathrm{Ag}_{35} \mathrm{Cu}_{10} \mathrm{Ga}_{55}$ & 650 & Liquid & & Liquid & $35.1 \pm 0.7$ & $9.5 \pm 0.6$ & $55.4 \pm 0.5$ \\
\hline 30 & $\mathrm{Ag}_{10} \mathrm{Cu}_{30} \mathrm{Ga}_{60}$ & 650 & Liquid & & Liquid & $9.5 \pm 0.6$ & $31.3 \pm 1.4$ & $59.2 \pm 1.2$ \\
\hline
\end{tabular}

Fig. 6 Calculated isothermal section of the $\mathrm{Ag}-\mathrm{Cu}-\mathrm{Ga}$ ternary system at $200{ }^{\circ} \mathrm{C}$ compared with the experimental results from this work

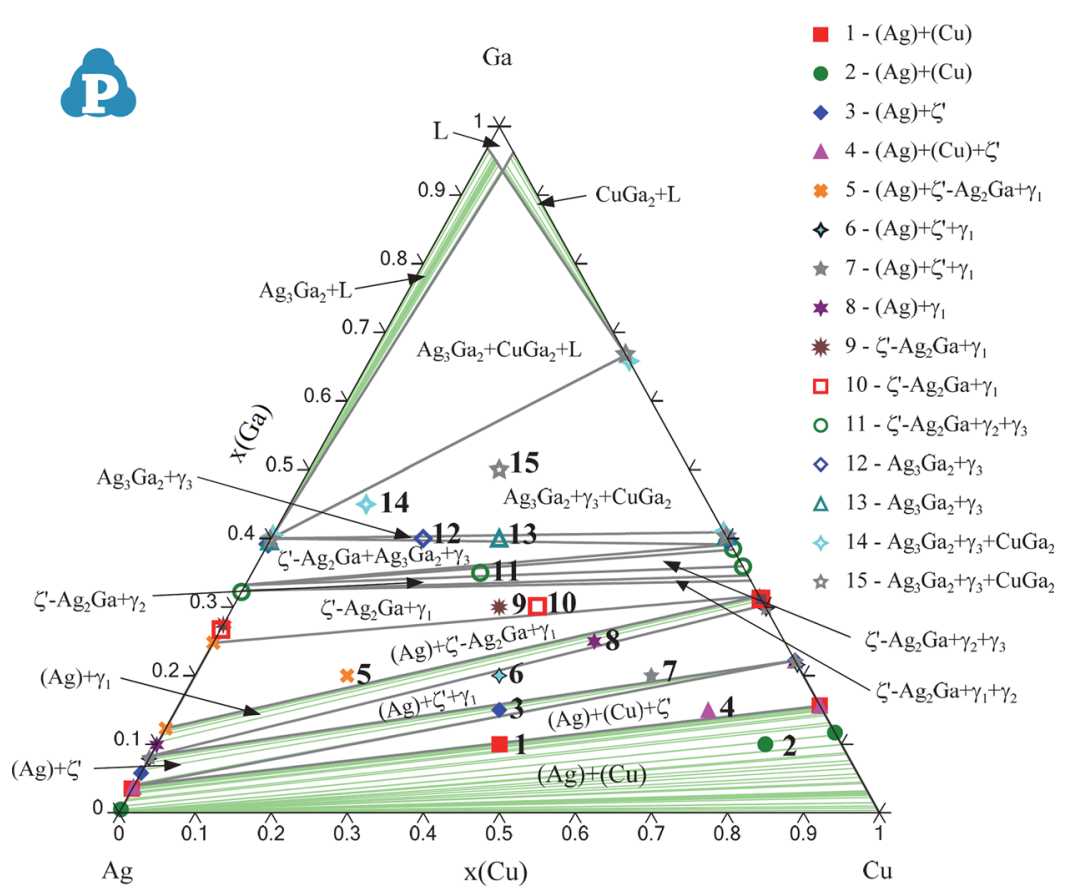


Fig. 7 Calculated isothermal section of the Ag-Cu-Ga ternary system at $450{ }^{\circ} \mathrm{C}$ compared with the experimental results from this work
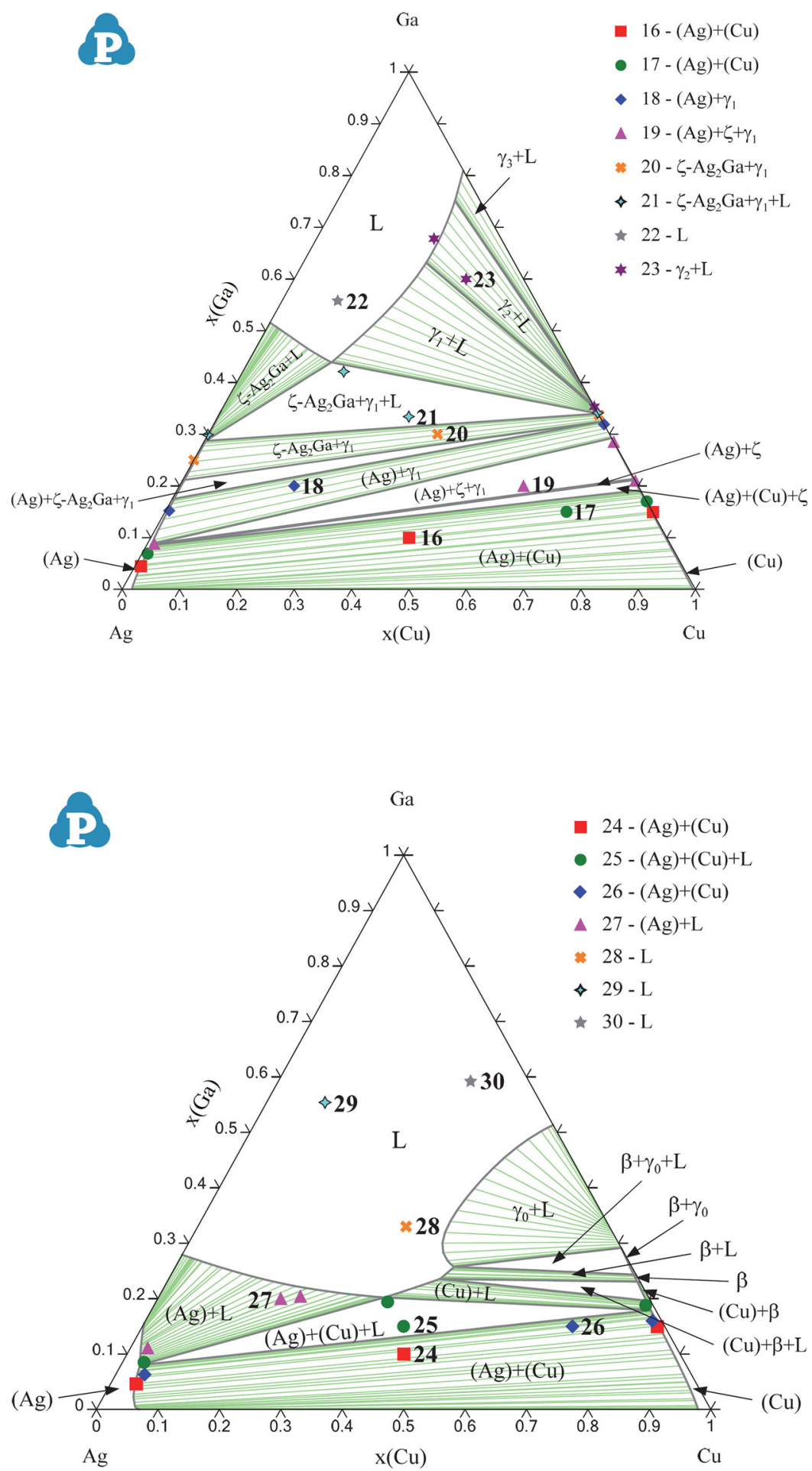

Fig. 8 Calculated isothermal section of the Ag-Cu-Ga ternary system at $650{ }^{\circ} \mathrm{C}$ compared with the experimental results from this work regions: $[(\mathrm{Ag})+(\mathrm{Cu}),(\mathrm{Ag})+$ liquid] and again one-phase field is the liquid phase.

The experimentally detected phases (XRD) and their compositions (SEM/EDS, Table 4) are compatible with the results of thermodynamic calculations (Fig. 6, 7, and 8).
The experimental results obtained from SEM/EDS and XRD methods are in good agreement with the calculation of the ternary $\mathrm{Ag}-\mathrm{Cu}-\mathrm{Ga}$ system. 


\section{Conclusions}

The phase equilibria in $\mathrm{Ag}-\mathrm{Cu}-\mathrm{Ga}$ system have been experimentally investigated by using DTA, SEM-EDS and XRD techniques. The analyses of fourteen samples, which were investigated by using DTA measurements, gave information about invariant reactions, other phase transitions as well as about liquidus temperatures. The comparison of the experimental results obtained along two crosssections $\left(x_{\mathrm{Ag}} / x_{\mathrm{Cu}}=1: 1\right.$ and $\left.x_{\mathrm{Ag}} / x_{\mathrm{Ga}}=1: 1\right)$ with calculated $\mathrm{Ag}-\mathrm{Cu}-\mathrm{Ga}$ system leads to the following conclusion: it seems that real liquidus surface is located in good agreement with the one obtained from the calculations. Experimentally determined temperatures of two invariant reactions $(* 240$ and $* * 294)$ are higher than those obtained from the calculations, while temperatures of two other invariant reactions $(* * * 405$ and $* * * * 496)$ are close to those obtained from the calculations. The comparison of temperatures of other phase transitions obtained from the experiment with the results of calculations also showed some discrepancy.

To determine phase equilibria in the $\mathrm{Ag}-\mathrm{Cu}-\mathrm{Ga}$ ternary system at constant temperature 200,450 and $650{ }^{\circ} \mathrm{C}, 30$ alloys were studied by applying SEM/EDS and XRD analysis. Descriptions of the isothermal sections of this ternary system (up to 60 at.\% of $\mathrm{Ga}$ ) at chosen temperatures are based on the experimental data. No ternary compounds were found in this system. Phases detected by EDS analysis are confirmed by XRD measurements. The calculated isothermal sections at 200,450 and $650{ }^{\circ} \mathrm{C}$ were found to be in good agreement with the results of EDS and XRD analysis (determined phases present in an equilibrium field and their compositions). Experimental results obtained in the present work were used in optimization of the phase diagram of ternary Ag-Cu-Ga system, ${ }^{[25]}$ from which ternary interaction parameters were taken derived.

Acknowledgments This work was carried out at AGH University of Science and Technology, Faculty of Non-Ferrous Metals under Grant Number 5854/B/T02/2010/39 and was supported by the Ministry of Science and Education. Authors thanks to G. Widła and J. Kusion for their help in experiments.

Open Access This article is distributed under the terms of the Creative Commons Attribution 4.0 International License (http://creative commons.org/licenses/by/4.0/), which permits unrestricted use, distribution, and reproduction in any medium, provided you give appropriate credit to the original author(s) and the source, provide a link to the Creative Commons license, and indicate if changes were made.

\section{References}

1. RG Medical Diagnostics, Material Safety Data Sheet for Galinstan, Wixom, MI, USA, 2006. http://www.rgmd.com/msds/msds. pdf
2. M. Hodes, R. Zhang, L.S. Lam, R. Wilcoxon, and N. Lower, On the Potential of Galinstan Based Minichannel and Minigap Cooling, IEEE Trans. Compon. Packag. Manuf. Technol., 2014, 4, $\mathrm{p}$ 46-56

3. C.A. McKay, Amalgams for Improved Electronics Interconnection, IEEE Micro, 1993, 4, p 46-58

4. R. Schmid-Fetzer, Fundamentals of Bonding by Isothermal Solidification for High Temperature Semiconductor Applications, in Design Fundamentals of High Temperature Composites, Intermetallics and Metal-Ceramic System, Proceedings of the 125th TMS Annual Meeting, Anaheim CA, USA, 4-8 Feb 1996, ed. by R.Y. Lin, Y.A. Chang, R.G. Reddy, and C.T. Liu (The Minerals, Metals \& Materials Society, Warrendale, 1996), p. 75-98

5. H.M. Chen, C.J. Guo, J.P. Huang, and H. Wang, Influence of Gallium Addition in Sn-Ag-Cu Lead-Fee Solder, J. Mater. Sci. Mater. Electron., 2015, 26, p 5459-5464

6. K. Wongpreedee, T. Tansakul, H.J. Schustere, and K. Chookruvong, Purple Gold: Past, Present, and Future to Ductile Intermetallics, in Gold 2006: New Industrial Applications for Gold, Limerick, Ireland (World Gold Council), 2006

7. J. Fischer-Buhner, A. Basso, and M. Poliero, New opportunities for blue and purple gold in jewelry casting, in The Santa Fe Symposium, E. Bell. 2009. Albuquerque, NM, USA. Met-Chem. Research, p. 151-166

8. C. Cretu and E. Lingen, Coloured Gold Alloys, Gold Bull., 1999, 32, $p$ 115-125

9. F.M. Blair, J.M. Whitworth, and J.F. McCabe, The Physical Properties of a Gallium Alloy Restorative Material, Dent. Mater., 1995, 11, p 277-280

10. H. Hero, C.J. Simensen, and R.B. Jorgensen, Structure of Dental Gallium Alloys, Biomaterials, 1996, 17, p 1321-1326

11. A.A. Likhachev and K. Ullakko, Magnetic-Field-Controlled Twin Boundaries Motion and Giant Magneto-Mechanical Effects in Ni-Mn-Ga Shape Memory Alloy, Phys. Lett. A, 2000, 275, p 142-151

12. V.V. Khovailo, V. Novosad, T. Takagi, D.A. Filippov, R.Z. Levitin, and A.N. Vasilev, Magnetic Properties and Magnetostructural Phase Transitions in $\mathrm{Ni}_{2}+\mathrm{xMn}_{1-\mathrm{x}} \mathrm{Ga}$ Shape Memory Alloys, Phys. Rev. B, 2004, 70, p 174413-1-7

13. J. Wang, A. Santamato, P. Jiang, D. Bonneau, E. Engin, J.W. Silverstone, M. Lermer, J. Beetz, M. Kamp, S. Höfling, M.G. Tanner, C.M. Natarajan, R.H. Hadfield, S.N. Dorenbo, V. Zwiller, J.L. O'Brien, and M.G. Thompson, Gallium Arsenide (GaAs) Quantum Photonic Wave Guide Circuits, Opt. Commun., 2014, 327, p 49-55

14. M. Uberschaar, S.J. Otto, and V.S. Rotter, Challenges for Critical Raw Material Recovery from WEEE-The Case Study of Gallium, Waste Manag., 2017, 60, p 534-545

15. S.P. DenBaars, D. Feezell, K. Kelchner, S. Pimputkar, C.C. Pan, C.C. Yen, S. Tanaka, Y. Zhao, N. Pfaff, R. Farrell, M. Iza, S. Keller, U. Mishra, J.S. Speck, and S. Nakamura, Development of Gallium-Nitride-Based Light-Emitting Diodes (LEDs) and Laser Diodes for Energy-Efficient Lighting and Displays, Acta Mater., 2013, 61, p 945-951

16. K.V.R.M. Murali, V.B. Naik, and D. Datta, Gallium-NitrideBased Light-Emitting Diodes, Resonance, 2015, 20, p 605-616

17. H. Du, C.H. Champness, I. Shih, and T. Cheung, Growth of Bridgman Ingots of $\mathrm{CuGa}_{x} \mathrm{In}_{1-x} \mathrm{Se}_{2}$ for Solar Cells, Thin Solid Films, 2005, 480, p 42-45

18. C.P. Muzzillo, C.E. Campbell, and T.J. Anderson, Cu-Ga-In Thermodynamics: Experimental Study, Modeling, and Implications for Photovoltaics, J. Mater. Sci., 2016, 51, p 3362-3379

19. C.P. Thompson, L. Chen, W.N. Shafarman, J. Lee, S. Fries, and R.W. Brikmire, Bandgap Gradients in $(\mathrm{Ag}, \mathrm{Cu})(\mathrm{In}, \mathrm{Ga}) \mathrm{Se}_{2}$ Thin Film Solar Cells Deposited by Three-Stage Co-Evaporation, in 2015 IEEE 42nd PhotovoltaicSpecialists Conference, IEEE, 2015 , p. $1-6$ 
20. V.Ya. Markiv, V.M. Maiorenko, and N.N. Belyavina, Phase Equilibria in the $\mathrm{Au}-\mathrm{Cu}-\mathrm{Ga}$ and $\mathrm{Ag}-\mathrm{Cu}-\mathrm{Ga}$ Systems, Russ. Metall., 1989, 6, p 189-191

21. D. Jendrzejczyk-Handzlik and K. Fitzner, Thermodynamic Properties of Liquid Silver-Gallium Alloys Determined from e.m.f. and Calorimetric Measurements, J. Chem. Thermodyn., 2011, 43, p 392-398

22. W. Gierlotka and D. Jendrzejczyk-Handzlik, Thermodynamic Description of the Binary Ag-Ga System, J. Alloys Compd., 2011, 509, p 38-42

23. D. Jendrzejczyk-Handzlik, P. Handzlik, and K. Fitzner, Enthalpies of Mixing of Liquid Ag-Ga, Cu-Ga and Ag-Cu-Ga Alloys, CALPHAD, 2014, 44, p 39-47

24. D. Jendrzejczyk-Handzlik, K. Fitzner, and W. Gierlotka, On the $\mathrm{Cu}-\mathrm{Ga}$ System: Electromotive Force Measurement and
Thermodynamic Reoptimization, J. Alloys Compd., 2015, 621, p 287-294

25. W. Gierlotka, D. Jendrzejczyk-Handzlik, K. Fitzner, and P. Handzlik, On the Ternary Ag-Cu-Ga System: Electromotive Force Measurement and Thermodynamic Modeling, J. Alloys Compd., 2015, 646, p 1023-1031

26. A.T. Dinsdale, A. Watson, A. Kroupa, A. Zemanova, J. Vrestal, J. Vizdal, COST 531 Thermodynamic Database, Version 3.0, 2008

27. A.T. Dinsdale, SGTE Pure Elements (Unary) Database, Version 4.5. 2006

28. W. Cao, S.-L. Chen, F. Zhang, K. Wu, Y. Yang, Y.A. Chang, R. Schmid-Fetzer, and W.A. Oates, PANDAT Software with PanEngine, PanOptimizer and PanPrecipitation for Multi-component Phase Diagram Calculation and Materials Property Simulation, CALPHAD, 2009, 33, p 328-342 